Un museo es, ante todo, un lugar oscuro y recóndito situado en un edificio muy antiguo, llegar a él debe ser difícil y a poder ser estará en la cima de una colina con múltiples escaleras. En su interior se guardan innumerables objetos antiguos junto a sabios de equivalente antigüedad, que los estudian y conservan para disfrute propio.

La finalidad básica de un museo es conservar los objetos e impedir que se destruyan. Para conseguir este propósito lo más efectivo es que nadie visite el museo y si alguien por casualidad lo consigue, debe estar en su interior el menor tiempo posible, no puede tocar nada y a poder ser que no vuelva nunca más.

Para conseguir todo ello se debe:

I. Hacer unos horarios de visita complicados y que induzcan a confusión. Deben cambiar y ser distintos cada día de la semana, con alternancias entre verano y invierno además de coincidir con los horarios laborales; ante todo debe conseguirse que los museos estén cerrados al mediodía, los sábados, domingos y demás festividades. También se cerrará durante las fiestas de Navidad, Semana Santa y los meses de julio y agosto. Los posibles visitantes deben desistir de entrar al museo y dedicarse a hacer cualquier otra cosa.

2. La dirección del museo no debe aparecer en ninguna guía y si aparece, la información debe ser mínima e indescifrable para que nadie lo encuentre. En los alrededores más próximos al museo ( $10 \mathrm{Km}$. como mínimo), siempre habrán señales anunciadoras del museo pero sin ninguna orientación para poder llegar.

3. La puerta debe estar cerrada a cal y canto, por razones de seguridad. Para entrar al museo se deberá mover una pesada verja y aporrear la aldaba de la puerta para que un vigilante nos permita la entrada al museo. La persona ideal para este puesto de trabajo es un funcionario, en edad de jubilación, de la última sobrante de la última reorganización del personal del municipio. La imagen es muy importante, su cara terrorífica y su cuerpo encorvado debe ahuyentar a cualquier atrevido que intente entrar.

4. Deben evitarse las guías de bolsillo, los itinerarios y las señalizaciones internas del museo, cualquier persona sensata que se aventure a visitarlo debe ser un erudito, el cual no necesita estas nimiedades. Al museo no se va para aprender nada sino a confirmar los conocimientos o como máximo a investigar.

5. Si se desean editar catálogos de exposiciones y colecciones, estos serán gruesos, científicos y muy lujosos. El nombre del director del museo aparecerá con grandes letras en la portada del libro (aunque sólo haya escrito la introducción). El precio será elevado, porque todo lo bueno es caro. Los folletos y las guías deben evitarse ya que sólo consiguen vulgarizar y empobrecer la categoría del centro.

6. Las exposiciones deben ser aburridas, con mucha letra pequeña e ilegible. Deben ser muy científicas, porque el museo es "la casa de las musas", las cuales siempre acompañan a las artes, la sabiduría y la ciencia. Los medios

\title{
EL MUSEO INEXPUGNABLE: DECÁLOGO
}

audiovisuales, las reconstrucciones de ambientes y los montajes atractivos y didácticos son propios de parques de atracciones y exposiciones de ciencia pero nunca de un lugar serio y aristocrático como el museo.

7. Nunca deben colocarse sillas, ni crear espacios de descanso, ni zonas donde poder leer plácidamente los catálogos y publicaciones del museo (si quieren leer algo que se lo compren). El público debe salir rápidamente del museo para poder cerrar lo más pronto posible. Una hora antes del límite horario nadie podrá entrar en el museo y se avisará -voz en grito- que todo el mundo debe irse.

8. El museo sirve para que los conservadores, especialmente el director, puedan investigar. Si algún investigador externo quiere consultar algún objeto no expuesto deberá seguir los siguientes trámites reglamentarios: debe llevar cinco cartas de presentación, llenar un formulario por triplicado, 3 fotografías y fotocopia del NIF. Una vez cumplidos todos los trámites se le impedirá ver el objeto con cualquier excusa: está en restauración o en alguna exposición en el extranjero.

9. La biblioteca del museo es para uso restringido interno, nadie y bajo ningún concepto debe entrar. Pero si alguien con insistencia lo consiguiera, debe desistir de su intento: no habrá ningún catálogo de clasificación y los libros estarán ordenados según un criterio personal e indescifrable.

10. Dentro del museo está prohibido hacer fotografías (con o sin flash), no se puede filmar (alguien podría pillar al vigilante haciendo calceta), tampoco pueden entrarse bolsos, por pequeños que sean (alguien podría llevarse una lápida en la cartera) y nadie puede acercarse a menos de un metro de cualquier objeto (sino sonará la alarma). En los museos solo se puede mirar y de lejos. Para evitar la contemplación innecesaria y reducir al máximo la estancia del público se esconderá convenientemente el lavabo y se cerrará con llave para uso restringido del personal.

\section{Norma adicional}

Para conseguir el máximo de efectividad en este reglamento del museo debe estar cerrado el mayor número de días al año. Para cerrar el museo pueden utilizarse distintas soluciones, todas ellas de comprobada fiabilidad: Por obras y reformas perpetuas e inacabables, por falta de vigilantes o por huelga de personal, este último requerirá la colaboración de los sindicatos.

Inspirado en "La Biblioteca de Babel", Umberto Eco (1983).

\author{
Daniel Solé i Lladós \\ Museólogo
}

El museo guarda en su interior innumerables objetos antiguos junto a sabios de equivalente antigüedad que los estudian y conservan para disfrute propio. 